Editor's Note: These short reviews of recent JNeurosci articles, written exclusively by students or postdoctoral fellows, summarize the important findings of the paper and provide additional insight and commentary. If the authors of the highlighted article have written a response to the Journal Club, the response can be found by viewing the Journal Club at www.jneurosci.org. For more information on the format, review process, and purpose of Journal Club articles, please see http://jneurosci.org/content/ preparing-manuscript\#journalclub.

\title{
Distinct Phases of Tau, Amyloid, and Functional Connectivity in Healthy Older Adults
}

\author{
Arielle S. Keller ${ }^{1}$ and Leigh Christopher ${ }^{2}$ \\ ${ }^{1}$ Stanford Neurosciences Graduate Program, and 2Department of Neurology and Neurological Sciences, Stanford University, Stanford, California 94305 \\ Review of Schultz et al.
}

Neurofibrillary tangles containing aggregates of abnormally phosphorylated tau protein are one of the main histological features of Alzheimer's disease. Until the recent advent of a positron emission tomography (PET) imaging tracer, these taucontaining tangles were not visible in the living human brain. Instead, many previous investigations of tau levels relied on measurements from CSF. Consequently, the progression of tau pathology during Alzheimer's disease had remained a mystery. Moreover, the relationships among tau tangles, $\beta$-amyloid plaques, and functional connectivity in the neural networks supporting cognition had not been well characterized. Given the limited clinical success of amyloid-targeted treatments thus far, many researchers have shifted their attention from amyloid to tau and their interactions (Giacobini and Gold, 2013), with the hope of uncovering how this dual pathology relates to the cognitive symptoms of Alzheimer's disease.

This new tau tracer, called $\mathrm{F}^{18}$-AV1451, was shown to bind strongly and with high specificity to neurofibrillary tangles in postmortem brain tissue samples (Mar-

\footnotetext{
Received June 16, 2017; revised July 28, 2017; accepted Aug. 3, 2017. We thank Dr. Katrin Andreasson and Dr. Yanmin Yang for their comments on this manuscript.

Correspondence should be addressed to Arielle $S$. Keller, Neurosciences Graduate Program, 1215 Welch Road, Modular B, \#42, Stanford, CA 94305. E-mail: arielleskeller@gmail.com.

DOI:10.1523/JNEUROSCI.1687-17.2017

Copyright $\odot 2017$ the authors $\quad 0270-6474 / 17 / 378857-03 \$ 15.00 / 0$
}

quié et al., 2015). Recently, Johnson et al. (2016) showed that the tau accumulation marked by this tracer is higher in patients with dementia than in healthy controls. In a study recently published in The Journal of Neuroscience, Schultz et al. (2017) explored the relationships among tau protein aggregates, amyloid plaques, and functional connectivity in healthy older adults. By examining the dynamic interactions among these measures in a large sample of elderly individuals, these researchers identified two distinct phases of amyloid and tau pathology that had not been reported previously.

Schultz et al. (2017) scanned the brains of 91 healthy older adult participants. Using ${ }^{18} \mathrm{~F}$-AV1451, they measured tau levels in three regions of interest known to accumulate tau neurofibrillary tangles with disease progression: entorhinal cortex, inferior temporal cortex, and inferior parietal cortex. In addition, they measured global amyloid levels with Pittsburgh compound $\mathrm{B}\left({ }^{11} \mathrm{C}-\mathrm{PiB}\right)$, and subsequently characterized participants as having a high or low amyloid burden. This characterization has previously been shown to predict the likelihood of episodic memory decline over time in nondemented individuals (Lim et al., 2014b). Finally, the authors used resting-state functional magnetic resonance imaging (rsfMRI) to measure coordinated activity among different brain areas in the resting brain.
Measures of the rsfMRI BOLD signal allowed the authors to infer functional connectivity within the following five cortical networks associated with a variety of cognitive functions: the default mode network (DMN), salience network (SAL), dorsal attention network, and left and right frontoparietal control networks. In older adults with high global amyloid burden, Schultz et al. (2017) found that functional connectivity within the DMN and SAL was significantly associated with amyloid and tau pathology. Specifically, high-amyloid individuals with low tau burden exhibited hyperconnectivity in the DMN and SAL, while those with high tau burden in addition to high amyloid exhibited hypoconnectivity in these networks. Given that the tau burden tends to increase over time, the authors interpret these two groups of older adults as representing two stages, whereby functional connectivity in these networks adapts to the accumulation of tau, initially with increased functional connectivity followed by reduced functional connectivity. Though longitudinal studies will be necessary to confirm this interpretation, discovery of these two groups of individuals by Schultz et al. (2017) elucidates important interactions among these critical predictors of disease progression.

The effect of tau in this interaction helps to explain previous mixed findings regarding resting state network connectivity in individuals with high amyloid 
burden (Hedden et al., 2009; Sheline and Raichle, 2013; Lim et al., 2014a). Although their results mainly emphasize the importance of tau pathology, Schultz et al. (2017) also acknowledge the consistency of their finding with the amyloid cascade hypothesis: only once amyloid has accumulated substantially in the brain does tau buildup appear to have a significant effect on functional connectivity. The authors also discuss the possibility that protective or compensatory mechanisms underlie the observed early hyperconnectivity phase. Early increases in functional connectivity could also be related to the finding that the disease is often comorbid with seizures, especially at early stages (Roberson et al., 2007; Palop and Mucke, 2009).

The finding that activity changes were restricted to the DMN and SAL is consistent with previous evidence that the DMN is disrupted in early Alzheimer's disease (Hedden et al., 2009), potentially leading to a cascade of network disruptions over time (Jones et al., 2016). The proposed involvement of both the DMN and SAL is especially interesting given that these two networks in particular are associated with attention and memory. Numerous studies have found that the DMN is associated with internally directed attention or "mind wandering" (Raichle, 2015) and autobiographical memory, while the SAL has been linked to externally directed or goaloriented attention (Seeley et al., 2007). Extensive research has demonstrated the interdependence of attention and memory, emphasizing the necessity of attention for successful memory encoding and recall. For example, lapses of attention during the encoding of information frequently lead to weak memory traces (Schacter, 1999). Therefore, the disruption of these attention networks provides a theoretical explanation for the link between these early markers of pathology and subsequent memory decline in Alzheimer's disease. This pattern also fits with the typical progression of symptoms: attention impairments begin in the early stages of the disease (Baddeley et al., 2001) followed by memory decline in the later stages.

Another important implication of the results found by Schultz et al. (2017) is that tau neurofibrillary tangles may disrupt connectivity to a greater extent than $\beta$-amyloid. This is consistent with the finding that tau levels more closely track patients' symptoms than amyloid levels (Nelson et al., 2012). Moreover, the relationship found between global amyloid and functional hyperconnectivity could imply that tau tangles and amyloid plaques have opposite effects on connectivity, with tau related to decreasing functional connectivity and amyloid related to increasing functional connectivity. This nuanced relationship between tau and amyloid may explain why it had previously been difficult to find a direct association between cognitive symptoms and amyloid burden alone. Furthermore, it highlights the importance of using PET imaging tau tracers like $\mathrm{F}^{18}$-AV1451 to gain a more complete understanding of Alzheimer's disease progression.

An alternative explanation of the association between tau pathology and hyperconnectivity may be related to the neural mechanisms underlying the spread of tau across the brain. Specifically, Wu et al. (2016) recently demonstrated activity-dependent modulation of tau release. Together with prior work showing that human tau can spread by cell-to-cell transmission across synapses (Mohamed et al., 2013), these findings suggest that the hyperactivity of neurons resulting from hyperconnectivity may lead to an increased spread of tau across the brain. Therefore, the results presented by Schultz et al. (2017) may suggest a new model of Alzheimer's disease progression, as follows: first, increasing amyloid in the earliest presymptomatic stages leads to network hyperconnectivity; second, this hyperconnectivity increases the spread of tau throughout the brain due to activitydependent modulation of tau release; and, finally, this spread of tau results in network hypoconnectivity. This model could be tested further in future studies to better characterize the mechanism of Alzheimer's disease progression.

These findings also hold implications for other forms of tauopathies such as chronic traumatic encephalopathy (CTE). Interestingly, CTE progression is associated with dysfunction in both the DMN and SAL (Sharp et al., 2014). The aforementioned mechanism of progression toward disease suggested by the results of the study by Schultz et al. (2017) may help to explain why those who already have abnormally high tau levels are more likely to develop Alzheimer's disease (Mendez, 2017). Similarly, major depressive disorder, which has been implicated as a risk factor for the development of Alzheimer's disease (Jorm, 2001), also involves dysfunction of the DMN (Wise et al., 2017). Together, these similarities suggest that it may be useful to develop treatments targeting these networks in particular, especially in individuals who are at higher risk of the development of dementia later in life.
Schultz et al. (2017) provided important contributions to the field of Alzheimer's disease research, demonstrating the effects of $\beta$-amyloid and tau on resting state functional connectivity. Future investigations should use a longitudinal approach to examine the interactions among plaques, tangles, and functional connectivity across the lifespan. Particularly, these studies should investigate even earlier presymptomatic stages, as protein aggregation can begin many years before symptom onset. Studies like these would have the potential to confirm the proposed phases of hyperconnectivity and hypoconnectivity, to assess whether these measures predict the development of pathology over time within individuals, and to inform the development of targeted preventative treatments.

\section{References}

Baddeley AD, Baddeley HA, Bucks RS, Wilcock GK (2001) Attentional control in Alzheimer's disease. Brain 124:1492-1508. CrossRef Medline

Giacobini E, Gold G (2013) Alzheimer disease therapy-moving from amyloid- $\beta$ to tau. Nat Rev Neurol 9:677-686. CrossRef Medline

Hedden T, Van Dijk KR, Becker JA, Mehta A, Sperling RA, Johnson KA, Buckner RL (2009) Disruption of functional connectivity in clinically normal older adults harboring amyloid burden. J Neurosci 29:12686-12694. CrossRef Medline

Johnson KA, Schultz A, Betensky RA, Becker JA, Sepulcre J, Rentz D, Mormino E, Chhatwal J, Amariglio R, Papp K, Marshall G, Albers M, Mauro S, Pepin L, Alverio J, Judge K, Philiossaint M, Shoup T, Yokell D, Dickerson B, Gomez-Isla T, Hyman B, Vasdev N, Sperling $\mathrm{R}$ (2016) Tau PET imaging in aging and early Alzheimer's disease. Ann Neurol 79: 110-119. CrossRef Medline

Jones DT, Knopman DS, Gunter JL, GraffRadford J, Vemuri P, Boeve BF, Petersen RC, Weiner MW, Jack CR Jr (2016) Cascading network failure across the Alzheimer's disease spectrum. Brain 139:547-562. CrossRef Medline

Jorm AF (2001) History of depression as a risk factor for dementia: an updated review. Aust N Z J Psychiatry 35:776-781. CrossRef Medline

Lim HK, Nebes R, Snitz B, Cohen A, Mathis C, Price J, Weissfeld L, Klunk W, Aizenstein HJ (2014a) Regional amyloid burden and intrinsic connectivity networks in cognitively normal elderly subjects. Brain 137:3327-3338. CrossRef Medline

Lim YY, Maruff P, Pietrzak RH, Ames D, Ellis KA, Harrington K, Lautenschlager NT, Szoeke C, Martins RN, Masters CL Villemagne VL, Rowe CC (2014b) Effect of amyloid on memory and non-memory decline from preclinical to clinical Alzheimer's disease. Brain 137:221-231. CrossRef Medline

Marquié M, Normandin MD, Vanderburg CR, Constantino IM, Bien EA, Rycyna LG, Klunk WE, Mathis CA, Ikonomovic MD, Debnath ML, Vasdev N, Dickerson BC, Gomperts SN, Growdon JH, Johnson KA, Frosch MP, Hyman BT, Gómez-Isla T (2015) Validating 
novel tau PET tracer [F-18]-AV-1451 (T807) on postmortem brain tissue. Ann Neurol 78: 787-800. CrossRef Medline

Mendez MF (2017) What is the relationship of traumatic brain injury to dementia? J Alzheimers Dis 57:667-681. CrossRef Medline

Mohamed N-V, Herrou T, Plouffe V, Piperno N, Leclerc N (2013) Spreading of tau pathology in Alzheimer's disease by cell-to-cell transmission. Eur J Neurosci 37:1939-1948. CrossRef Medline

Nelson PT, Alafuzoff I, Bigio EH, Bouras C, Braak H, Cairns NJ, Castellani RJ, Crain BJ, Davies P, Del Tredici K, Duyckaerts C, Frosch MP, Haroutunian V, Hof PR, Hulette CM, Hyman BT, Iwatsubo T, Jellinger KA, Jicha GA, Kövari E, et al. (2012) Correlation of Alzheimer disease neuropathologic changes with cognitive status: a review of the literature. J Neuropathol Exp Neurol 71:362-381. CrossRef Medline

Palop JJ, Mucke L (2009) Epilepsy and cognitive impairments in Alzheimer disease. Arch Neurol 66:435-440. CrossRef Medline

Raichle ME (2015) The brain's default mode network Annu Rev Neurosci 38:433-447. CrossRef Medline

Roberson ED, Scearce-Levie K, Palop JJ, Yan F, Cheng IH, Wu T, Gerstein H, Yu GQ, Mucke L (2007) Reducing endogenous tau ameliorates amyloid beta-induced deficits in an Alzheimer's disease mouse model. Science 316: 750-754. CrossRef Medline

Schacter DL (1999) The seven sins of memory. Insights from psychology and cognitive neuroscience. Am Psychol 54:182-203. CrossRef Medline

Schultz AP, Chhatwal JP, Hedden T, Mormino EC, Hanseeuw BJ, Sepulcre J, Huijbers W, LaPoint M, Buckley RF, Johnson KA, Sperling RA (2017) Phases of hyperconnectivity and hypoconnectivity in the default mode and salience networks track with amyloid and tau in clinically normal individuals. J Neurosci 37: 4323-4331. CrossRef Medline

Seeley WW, Menon V, Schatzberg AF, Keller J, Glover GH, Kenna H, Reiss AL, Greicius MD (2007) Dissociable intrinsic connectivity networks for salience processing and executive control. J Neurosci 27:2349-2356. CrossRef Medline

Sharp DJ, Scott G, Leech R (2014) Network dysfunction after traumatic brain injury. Nat Rev Neurol 10:156-166. CrossRef Medline

Sheline YI, Raichle ME (2013) Resting state functional connectivity in preclinical Alzheimer's disease. Biol Psychiatry 74:340-347. CrossRef Medline

Wise T, Marwood L, Perkins AM, Herane-Vives A, Joules R, Lythgoe DJ, Luh WM, Williams SCR, Young AH, Cleare AJ, Arnone D (2017) Instability of default mode network connectivity in major depression: a two-sample confirmation study. Transl Psychiatry 7:e1105. CrossRef Medline

Wu JW, Hussaini SA, Bastille IM, Rodriguez GA, Mrejeru A, Rilett K, Sanders DW, Cook C, Fu H, Boonen RA, Herman M, Nahmani E, Emrani S, Figueroa YH, Diamond MI, Clelland CL, Wray S, Duff KE (2016) Neuronal activity enhances tau propagation and tau pathology in vivo. Nat Neurosci 19:1085-1092. CrossRef Medline 